\title{
Chemical constituents of water hyacinth (Eichhornia crassipes) methanol leaf extract and its effect on selected enzymes of Periplaneta americana
}

\author{
Gbadebo E. Adeleke, Olaniyi T. Adedosu, Leonard Ehigie, Peter I. Adegbola*, \\ Adekunle A. Olaniyi, Temitope O. Agoola, Adeola F. Ehigie \\ Department of Biochemistry, Faculty of Basic Medical Sciences, Ladoke Akintola University of Technology, Ogbomoso, Nigeria
}

\begin{abstract}
Eichhornia crassipes (water hyacinth) possesses several biological properties. Periplaneta americana (cockroach) is a household insect pest that can disseminate pathogens. The present study analyses the chemical constituents of water hyacinth leaf methanol extract and its in vitro effects on antioxidant and esterase enzymes in cockroaches. Water hyacinth methanol extract (WHME) was subjected to gas chromatography-flame ionization detection (GC-FID). Crude enzyme preparations were obtained from nymph and adult cockroaches. In vitro effects of different concentrations $(10-80 \mu \mathrm{g} / \mathrm{ml})$ of WHME on superoxide dismutase (SOD), catalase (CAT), glutathioneS-transferase (GST), acetylcholinesterase (AChE), and carboxylesterase (CE) in crude enzyme preparations were spectrophotometrically measured using cypermethrin (CYP) and chlorpyrifos (CPF) as reference insecticides. The GC-FID chromatogram of WHME showed the presence of gallic acid, para-hydroxybenzoic acid, eritosin, gentisic acid, catechin, protocatechuric acid, quercetin, and eugenol. The WHME and CPF reduced catalase in adults and SOD in nymphs, while CYP and CPF reduced SOD activity in the adults of $P$. americana. GST was significantly increased by WHME in both nymph and adult cockroaches. AChE was reduced by WHME, CYP, and $\mathrm{CPF}$ in nymphs, while CE was increased by WHME in nymphs and adults as compared to the control. In conclusion, our study indicates a high phenolic content in the water hyacinth leaf methanol extract, which increased the activities of the antioxidant enzymes AChE and CE in $P$. americana. The results also show that the efficacy and the mode by which the extracts could induce toxicity depend on the growth stage of the cockroach.
\end{abstract}

Key words: Eichhornia crassipes, spectroscopy, chromatography, Periplaneta americana, antioxidant enzymes, esterases

\section{Introduction}

The adult American cockroach (Periplaneta americana) is a large species of approximately $34-53 \mathrm{~mm}$ long. It is reddish brown with substantial variations in the light and dark patterns on the protum. The nymphs typically complete the developmental stages in approximately 2 years by undergoing a series of molts (Brenner and Kramer, 2019). Cockroach is perhaps the most cosmopolitan peridomestic pest species, which is believed to have spread from tropical Africa to North America (Brenner and Kramer, 2019). A high population of cockroaches may adversely affect human health through the contamination of food with their excreta, biting, and dissemination of pathogens, thereby inducing allergies, physiological stress, wounds, and blisters (Pomes et al., 2007; Bonnefoy et al., 2008; Ozdemir, 2014; Brenner and Kramer, 2019). Apart from their health impact, cockroaches are known to be destructive as they feed on books, leather, wallpaper paste, and even household furniture (Anonymous, 2004). They are among the most difficult household pests to control. Integrated methods of control involve the use of mechanical, physical, chemical, and/or biological means (Christopher, 2002; Mullen and Durden, 2002; Piper and Antoneli, 2007; Brenner and Kramer, 2019). The most effective method is chemical control which may be in the form of surface spray,

\footnotetext{
* Corresponding author: Department of Biochemistry, Faculty of Basic Medical Sciences, Ladoke Akintola University of Technology, Ogbomoso, Nigeria; e-mail: useablevesselofgod@gmail.com; piadegbola27@lautech.edu.ng
} 
space spray, and insecticide baits (Ogunleye, 2010). However, chemical pesticides may be highly hazardous to human health, increase insect resistance, and cause general ecological problems; therefore, they need to be replaced with eco-friendly alternatives (Anchor Pest Control, 2008). Plant-derived insecticides could serve as suitable alternatives as plants contain a wide variety of bioactive compounds that protect them against herbivorous insects (Ennan et al., 1998; Tholl, 2006). In addition, plant-derived extracts and essential oils have been proven to be effective, are easily biodegradable, and are considered to be safe and cheap alternative sources of new insecticides (Bhat et al., 2012; Yu et al., 2012; Dhivya et al., 2017; Stevenson et al., 2017).

Synthetic insecticides are reported to affect untargeted animal species through environmental pollution, thus causing resurgence and pesticide resistance in the targeted insects. The use of alternative strategies based on botanical agents has therefore become a highly desired approach (Valicentre et al., 2010; Lenora and Senthilkumar, 2017; Acero, 2018). Many of the chemical insecticides act through mechanisms that involve inhibition of acetyl cholinesterase (AChE) and other molecular and cellular targets through overproduction of reactive oxygen species (ROS) (ZhuandClark, 1997; Milatovic et al., 2006; Lionetto et al., 2011). Similar mechanisms of insecticidal toxicity have been suggested for certain botanical pesticides, as reported by Isman (2006), Lima (2006), Pavela and Benelli (2016), and Adeleke et al. (2019a, b).

Plants contain several secondary metabolites such as alkaloids, terpenes, glucosinolates, and phenolics, which prevent insects and microbial pests from attacking them (Freedman and Beattie, 2008). Eichhornia crassipes (water hyacinth) is a free-floating aquatic plant of the Pontederiaceae family (Xie et al., 2010; Annie et al., 2015). This plant is indigenous to Amazonia in Brazil (Barrett and Forno, 1982) and has spread to other places such as India, Egypt, Java, and Australia (Gopal, 1987) as well as Central South America, Venezuela, and the Caribbean Islands (Edward and Musil, 1975). The plant is known for its invasive nature (Villamagna and Murphy, 2010) and has been reported to contain bioactive constituents including stigmasterol, campesterol, $\beta$-sitosterol (Goswami et al., 1983), and naringenin (Bido et al., 2010) as well as alkaloids, flavonoids, sterols, anthraquinones (Jayanthi et al., 2011; Lalitha et al., 2012), and terpenoids (Shanab et al., 2010). Studies have revealed that water hyacinth has antimicrobial (Jayanthi and Lalitha, 2013), anti-inflammatory (Jayanthi et al., 2013), antitumor (Ali et al., 2009), antioxidant (Liu et al., 2010), and wound healing properties (Ali et al., 2010). A few studies have shown the insecticidal properties of water hyacinth extracts against some crop and household insects (Hassan, 2013; Annie et al., 2015; Chaudhary et al., 2017). The present study was designed to investigate the chemical constituents of methanol extract of water hyacinth leaf and its possible in vitro effects on some antioxidant and esterase enzymes in nymph and adult $P$. americana.

\section{Materials and methods}

\section{Chemicals}

Acetylthiocholine iodide, para-nitrophenyl acetate, 4-nitrophenol, and adrenaline (Sigma) were purchased from Germany, while Triton X-100, ethylenediamine tetraacetic acid (EDTA), and dithionitrobenzoic acid (DTNB) were purchased from the British Drug House Chemical Limited (Poole, UK). Two commercial insecticides, namely cypermethrin (CYP) and chlorpyrifos (CPF) (Sichuan Leschan Fuhua Tongda Agrochemical Technology Co. Ltd, China), were purchased from the TJP Agrochemical store in Ogbomoso, Oyo state, Nigeria. Other chemicals were of analytical grades and the purest quality available.

\section{Collection and extraction of water hyacinth (E. crassipes)}

The leaves of water hyacinth (E. crassipes) were collected at Olubere River, Ogbomoso (Oyo state, Nigeria) in March 2019. The greenish-yellow leaves were air dried at room temperature for approximately 3 weeks and then pulverized to obtain coarse powder. The powder was subjected to Soxhlet extraction using methanol to obtain the water hyacinth methanol extract (WHME). The extract was concentrated using a rotary evaporator and then subjected to oven drying at $40^{\circ} \mathrm{C}$ to obtain a dry powder. The concentrated extract was kept in an airtight container at $4^{\circ} \mathrm{C}$ until use.

\section{Chemical analysis of methanol extract of water hyacinth}

\section{Ultraviolet (UV) and Fourier transform-infrared (FTIR) spectroscopic analyses}

The UV spectra of WHME were obtained on a UV1800 series spectrophotometer (Shimadzu) at the wavelength of $340 \mathrm{~nm}$, while the IR spectra were obtained on 
a Cary 630 FTIR spectrophotometer (Agilent). The wavelength was expressed in reciprocal centimetre $\left(\mathrm{cm}^{-1}\right)$. The spectral data in both analyses were compared with literature data.

\section{Gas chromatography-flame ionization detection (GCFID)}

GC-FID identification of compounds in the WHME was performed on HP SERIES II (5890) coupled to a flame ionization detector. Nitrogen was used as the carrier gas at the flow rate of $20 \mathrm{ml} / \mathrm{min}$ and hydrogen/compressed air was used as the combustion gas at the flow rate of $45 \mathrm{ml} / \mathrm{min}$. The initial, and the injector and detector temperatures were $50^{\circ} \mathrm{C}, 220^{\circ} \mathrm{C}$ and $270^{\circ} \mathrm{C}$, respectively, while the oven temperature was programmed to $240^{\circ} \mathrm{C}$ at the rate of $10^{\circ} \mathrm{C} / \mathrm{min}$ with a holding time of $2 \mathrm{~min}$. Chemical constituents were identified by comparing the mass spectra with the standard available in the NIST 11 library. The percentage composition of each constituent was estimated from the peak area of the chromatogram

\section{Collection and homogenization of insect (P. americana)}

Forty nymph and adult cockroaches $(P$. americana) were collected separately from a dark cupboard at a residence in Ogbomoso (Oyo state, Nigeria) in March 2019. The adult insects were de-winged, and both nymphs and adults were divided into two groups (20 insects each). To determine the carboxylesterase (CE) activity, the first group was homogenized using phosphate buffer solution ( $\mathrm{pH}$ 7.4), while the second group was homogenized with Tris- $\mathrm{HCl}$ buffer solution ( $\mathrm{pH}$ 7.8). The insect homogenates were then centrifuged using a refrigerated centrifuge at $10000 \times g$ for $10 \mathrm{~min}$ at $4^{\circ} \mathrm{C}$. The supernatants were collected and kept at $4^{\circ} \mathrm{C}$ until analysis.

\section{Quantitative determination of the total protein content in $P$. americana homogenates}

The total protein content in the nymph and adult $P$. americana homogenates was estimated spectrophotometrically at $546 \mathrm{~nm}$ as described by Lowry et al. (1951).

\section{Enzyme analysis}

\section{Superoxide dismutase (SOD) activity}

The activity of superoxide dismutase (SOD) in insects was estimated as described by Misra and Fridovich (1975). Briefly, an aliquot of $0.2 \mathrm{ml}$ of the diluted insect homogenate (crude enzyme preparation) was added to $2.5 \mathrm{ml}$ of $0.05 \mathrm{M}$ carbonate buffer solution ( $\mathrm{pH} 10.2$ ) for equilibration in the spectrophotometer. Then, $0.2 \mathrm{ml}$ of WHME, CYP and CPF each was separately added at the following concentrations of $10,20,30,40,50,60,70$ and $80 \mu \mathrm{g} / \mathrm{ml}$ in triplicates. The reaction was then initiated by adding $0.3 \mathrm{ml}$ of freshly prepared $0.3 \mathrm{mM}$ adrenaline to the mixture, which was quickly mixed by inversion. The absorbance at $480 \mathrm{~nm}$ was spectrophotometrically monitored every $30 \mathrm{~s}$ for $150 \mathrm{~s}$. The SOD activity was calculated using the equation below by considering molar extinction of SOD at $480 \mathrm{~nm}$ as $525 \mathrm{M}^{-1} \cdot \mathrm{cm}^{-1}$.

SOD activity [Unit $/ \mathrm{mg}$ protein $]=$

$$
=\frac{\text { absorbance } \times \text { volume of mixture }}{\varepsilon_{480 \mathrm{~mm}} \times \text { sample vol } \times \mathrm{mg} \text { protein }}
$$

Molar extinction of SOD at $480 \mathrm{~nm}\left(\varepsilon_{480 \mathrm{~mm}}\right)=525 \mathrm{M}^{-1} \cdot \mathrm{cm}^{-1}$

\section{Catalase activity}

The method described by Aebi (1984) was used to determine the catalase activity in the insect homogenates. The assay mixture contained $4 \mathrm{ml}$ of hydrogen peroxide solution $(0.2 \mathrm{M})$ and $5 \mathrm{ml}$ of phosphate buffer $(0.01 \mathrm{M}, \mathrm{pH} 7.0)$ in a $10 \mathrm{ml}$ flat bottom flask. An aliquot of $1.0 \mathrm{ml}$ of appropriately diluted crude enzyme preparation (homogenate) was mixed with the reaction mixture by a gentle swirling motion, and $0.3 \mathrm{ml}$ of WHME, CYP and $\mathrm{CPF}$ was added separately at the following concentrations of $10,20,30,40,50,60,70$ and $80 \mu \mathrm{g} / \mathrm{ml}$ in triplicates. The reaction was run at room temperature. An aliquot of $1 \mathrm{ml}$ of the reaction mixture was blown into $2 \mathrm{ml}$ of dichromate/acetic acid reagent at $60 \mathrm{~s}$ intervals. The changes in absorbance were monitored for $180 \mathrm{~s}$ at an interval of $60 \mathrm{~s}$ at $240 \mathrm{~nm}$ wavelength. The enzyme activity was calculated using the formula given below:

$$
\begin{gathered}
\mathrm{H}_{2} \mathrm{O}_{2} \text { remained }=\frac{\text { change in absorbance per minute }}{0.171} \\
\mathrm{H}_{2} \mathrm{O}_{2} \text { consumed }=200-\mathrm{H}_{2} \mathrm{O}_{2} \text { remained } \\
\mathrm{K}_{0}=\mathrm{H}_{2} \mathrm{O}_{2} \text { consumed } \\
\text { Catalase activity }=\mathrm{K}_{0} / \mathrm{mg} \text { protein } \\
\text { Catalase activity }=\text { Unit } / \mathrm{mg} \text { protein }
\end{gathered}
$$

\section{Glutathione-S-transferase (GST) activity}

Glutathione-S-transferase (GST) activity was determined according to the method described by Habig et al. 
(1974). The reaction mixture contained $30 \mu \mathrm{l}$ of GSH $(0.1 \mathrm{M}), 150 \mu \mathrm{l}$ of 1-chloro-2,4-dinitrobenzene (CDNB) (20 mM), $1.5 \mathrm{ml}$ of phosphate buffer (0.1 M, pH 6.5), $50 \mu \mathrm{l}$ of crude enzyme preparation and $30 \mu \mathrm{l}$ of WHME, CYP and CPF (separately added at the concentrations of $10,20,30,40,50,60,70$ and $80 \mu \mathrm{g} / \mathrm{ml}$ ) added in a sequential order. The blank contained $30 \mu \mathrm{l}$ of GSH, $150 \mu \mathrm{l}$ of CDNB and $1.5 \mathrm{ml}$ of phosphate buffer ( $\mathrm{pH} 6.5)$. The reaction was allowed to run for $60 \mathrm{~s}$ at $31^{\circ} \mathrm{C}$ before the absorbance was read spectrophotometrically against the blank at $340 \mathrm{~nm}$. All analyses were performed in triplicates for each sample analysed. The GST activity was calculated using the formula given below by considering the extinction coefficient of CDNB as $9.6 \mathrm{mM}^{-1} \cdot \mathrm{cm}^{-1}$

GST specific activity $[\mu \mathrm{M}$ conjugate $/ \mathrm{min} / \mathrm{mg}$ protein $]=$

$$
=\frac{\mathrm{OD} / \mathrm{min}}{9.6} \times \frac{1}{0.03 \mathrm{ml} / \mathrm{mg} \text { protein }}
$$

\section{AChE Activity}

The method described by Nachmanshon and Neumann (1975) and Ellman et al. (1961) was used to measure the activity of AChE. Briefly, $2.6 \mathrm{ml}$ of phosphate buffer (0.1 M, pH 7.4), $0.1 \mathrm{ml}$ of Ellman's reagent, 5, $5^{\prime}$-dithio-bis 2-nitrobenzoic acid (DTNB), $0.4 \mathrm{ml}$ of the crude enzyme preparation (insect homogenate), and $0.3 \mathrm{ml}$ of WHME, CYP and CPF each (at the concentrations of $10,20,30,40,50,60,70$ and $80 \mu \mathrm{g} / \mathrm{ml}$ ) were added to the reaction tubes. An aliquot of $0.1 \mathrm{ml}$ of acetylthiocholine iodide solution was added to the reaction mixture as the substrate for the enzyme. The change in absorbance at $412 \mathrm{~nm}$ was read for $10 \mathrm{~min}$ at intervals of $2 \mathrm{~min}$. The AChE activity was calculated using the formula given below by assuming the molar extinction to be $1.361 \mathrm{mmol}^{-1} \cdot \mathrm{mm}^{-1}$.

AChE activity $[\mathrm{U} / \mathrm{mg}$ protein $]=$

$$
\begin{aligned}
& =\frac{\Delta \mathrm{A} \times \text { total reaction volume }}{\text { time } \times \text { sample volume } \times \text { molar extinction }} \\
& \mathrm{AChE} \text { activity }=\mathrm{U} / \mathrm{mg} \text { protein }
\end{aligned}
$$

\section{CE Activity}

The activity of $\mathrm{CE}$ enzyme was determined using the method described by Clement and Erhardt (1990), with some modifications. Each of the 20 nymph and de-winged adult cockroaches were homogenized in ice-cold Tris-HCl buffer $(0.1 \mathrm{M}$ Tris-HCl, $\mathrm{pH} 7.8$ with $1 \%$ Triton $\mathrm{X}$-100) using a tissue homogenizer. The homogenate was centrifuged in a refrigerated centrifuge at $10000 \times g$ for $10 \mathrm{~min}$ at $4^{\circ} \mathrm{C}$. The supernatant was diluted with distilled water in $1: 10$ ratio. The reaction mixture contained $0.5 \mathrm{ml}$ of diluted crude enzyme preparation (supernatant) and $2 \mathrm{ml}$ of the working buffer $(0.1 \mathrm{M}$ Tris $\mathrm{HCl}$, $\mathrm{pH} 7.8$, containing $2 \mathrm{mM}$ EDTA at $25^{\circ} \mathrm{C}$ ), followed by $0.3 \mathrm{ml}$ of WHME, CYP and CPF each (at the concentrations of $10,20,30,40,50,60,70$ and $80 \mu \mathrm{g} / \mathrm{ml})$. The mixture was incubated at $37^{\circ} \mathrm{C}$ for $10 \mathrm{~min}$, and the reaction was initiated by adding $0.2 \mathrm{ml}$ of $50 \mathrm{mM}$ paranitrophenyl acetate (in acetone) as a substrate. The change in absorbance was measured spectrophotometrically at $405 \mathrm{~nm}$ at an interval of $1 \mathrm{~min}$ for $5 \mathrm{~min}$. The blank reagent contained $2 \mathrm{ml}$ working buffer and $0.2 \mathrm{ml}$ paranitrophenyl acetate. A standard solution of paranitrophenol ( $50 \mathrm{mM}$ ) was used to evaluate the $\mathrm{CE}$ activity by using the following formula:

Carboxylesterase activity $=$

$=\frac{\text { absorbance of sample }}{\Delta \text { absorbance of standard }} \times$ concentration standard

Carboxylesterase activity $=\mathrm{mM} / \mathrm{min} / \mathrm{mg}$ protein

\section{Statistical analysis}

All values are expressed as mean \pm SD. Differences in the mean values were analysed statistically by one-way analysis of variance (ANOVA) by using SPSS and were considered to be significant at $P<0.05$.

\section{Results}

\section{Spectral and chromatographic analyses}

This study conducted IR and UV spectroscopy of the WHME to detect various compounds present in it. As shown in Figure 1, the IR exhibited five prominent peaks at $1015.7 \mathrm{~cm}^{-1}, 1457.4 \mathrm{~cm}^{-1}, 1647.5 \mathrm{~cm}^{-1}, 2927.8 \mathrm{~cm}^{-1}$ and $3324.8 \mathrm{~cm}^{-1}$, while as shown in Figure 2, the UV spectrum exhibited maximal absorption at the wavelength range of 223-228 nm. The GC-FID chromatogram of WHME (Fig. 3) shows 10 different compounds with their respective retention times and percentage peak areas as follows: gallic acid (9.133 min, 9.73\%), para-hydroxybenzoic acid (10.983 min, 7.23\%), katekin (11.283 min, $4.95 \%)$, eritosin (11.550 min, 5.32\%), gentisic acid (12.350 min, $12.59 \%)$, catechin (13.416 min, $7.31 \%$ ), protocatechuic acid (14.233 min, 9.31\%), kuersetin (15.216 min, 8.94\%), quercetin (15.866 min, 28.52\%) and eugenol (17.150 $\mathrm{min}, 6.10 \%)$. 


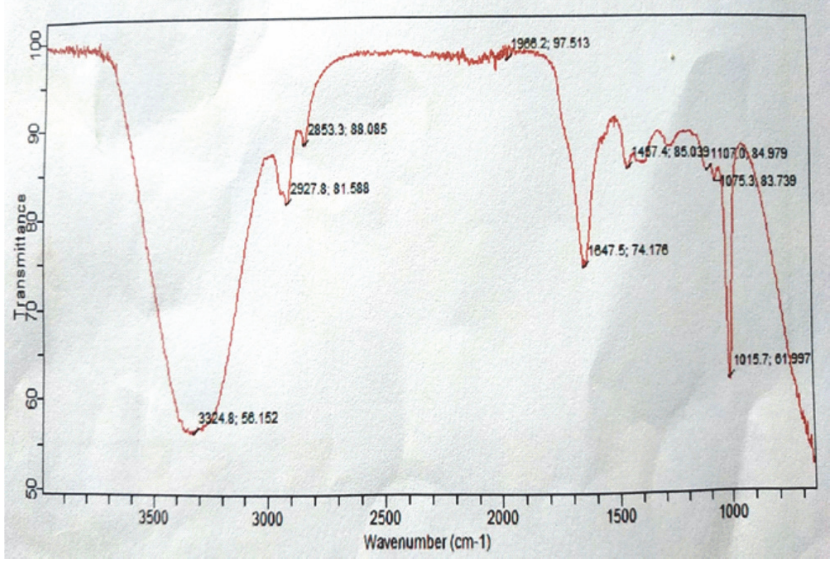

Fig. 1. Infrared spectrum of water hyacinth methanol extract (WHME) (shows five prominent peaks at $1015.7 \mathrm{~cm}^{-1}$, $1647.5 \mathrm{~cm}^{-1}, 2853.3 \mathrm{~cm}^{-1}, 2929.8 \mathrm{~cm}^{-1}, 3324.8 \mathrm{~cm}^{-1}$ )

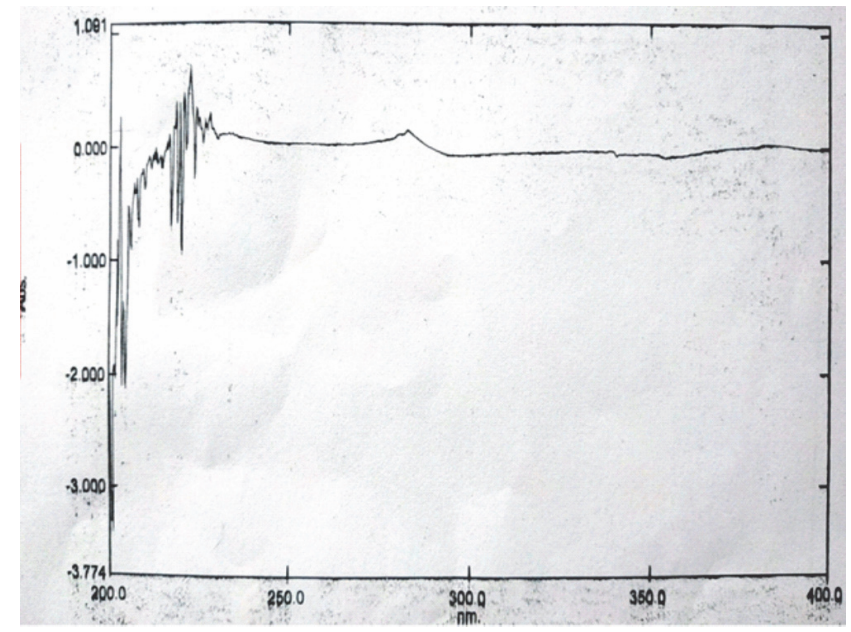

Fig. 2. Ultraviolet spectrum of water hyacinth methanol extract (WHME) (shows highest absorbance at a wavelength range between $223-228 \mathrm{~nm}$ )

\section{Antioxidant enzymes}

Table 1 shows the effects of the WHME, CYP and $\mathrm{CPF}$ on the catalase activities in both nymph and adult $P$. americana. The result showed a significant increase $(P<0.05)$ in catalase activities following in vitro treatment with WHME, CYP and CPF in nymph $P$. americana when compared with that in the control. The catalase activity in the WHME-treated adult insect homogenate decreased significantly at $10 \mu \mathrm{g} / \mathrm{ml}(1.11 \pm 0.13), 30 \mu \mathrm{g} / \mathrm{ml}$ $(1.00 \pm 0.01), \quad 70 \mu \mathrm{g} / \mathrm{ml}(1.30 \pm 0.01)$ and $80 \mu \mathrm{g} / \mathrm{ml}$ (1.26 \pm 0.06$)$, but only at $60 \mu \mathrm{g} / \mathrm{ml}(0.99 \pm 0.01)$ and $70 \mu \mathrm{g} / \mathrm{ml}(1.20 \pm 0.01)$ for CPF. In contrast, the activity was significantly reduced by CYP at all the concentrations tested when compared with that in the control (Table 1). The activity of SOD was significantly reduced
$(P<0.05)$ by WHME at $30 \mu \mathrm{g} / \mathrm{ml}(0.99 \pm 0.01), 40 \mu \mathrm{g} / \mathrm{ml}$ $(1.99 \pm 0.01), \quad 70 \mu \mathrm{g} / \mathrm{ml}(0.99 \pm 0.01)$ and $80 \mu \mathrm{g} / \mathrm{ml}$ $(0.94 \pm 0.09)$ and by CPF only at $60 \mu \mathrm{g} / \mathrm{ml}(1.96 \pm 0.06)$ and $80 \mu \mathrm{g} / \mathrm{ml}(0.99 \pm 0.01)$. CPY significantly reduced $(P<0.05)$ SOD activity at all concentrations tested, except at $10 \mu \mathrm{g} / \mathrm{ml}(2.95 \pm 0.07)$ where the activity increased significantly $(P<0.05)$ in the nymphs (Table 2$)$. However, in the adult cockroaches, WHME significantly elevated SOD activity, while both CYP and CPF lowered the enzyme activity across all concentrations tested, as shown in Table 2. Figure 4 and Figure 5 show the activities of GST in both nymph and adult cockroaches. WHME significantly increased $(P<0.05)$ the GST activity (ranging from $18.5 \pm 2.21$ to $22.42 \pm 2.11$ and $14.85 \pm 1.10$ to $15.61 \pm 2.01$ for nymph and adult cockroaches, respectively), while CPF significantly reduced $(P<0.05)$ the activity at all the concentrations tested $(10-80 \mu \mathrm{g} / \mathrm{ml})$. On the other hand, CYP was observed to significantly reduce the GST activity only at certain concentrations in both nymph and adult cockroaches when compared with the control $(12.82 \pm 0.97)$.

\section{Esterase enzymes}

A study of the AChE activity showed that WHME ( $4.00 \pm 0.03$ to $11.20 \pm 0.12)$, CYP $(0.8 \pm 0.01$ to $17.6 \pm 1.63)$ and $\mathrm{CPF}(1.00 \pm 0.01$ to $5.10 \pm 0.46)$ significantly reduced $(P<0.05)$ the activity at all the concentrations tested in the nymph $P$. americana when compared with the control $(21.70 \pm 2.33)$ (Fig. 6). Figure 7 shows that WHME exerted no significant effect $(P>0.05)$ on the AChE activity in the adult insect. Furthermore, although CYP reduced the AChE activity, CPF increased it at all the concentrations $(10-80 \mu \mathrm{g} / \mathrm{ml})$ used in adults when compared with the control treatment (Fig. 7). The activity of $\mathrm{CE}$ was increased by both WHME and CPF at nearly all the concentrations tested, whereas CYP reduced it at nearly all the concentrations tested in nymph $P$. americana when compared with the control treatment (Fig. 8). The CE activity in adults was significantly increased $(P<0.05)$ by WHME at all the concentrations, except at $40 \mu \mathrm{g} / \mathrm{ml}(6.51 \pm 0.14), 50 \mu \mathrm{g} / \mathrm{ml}$ $(5.90 \pm 0.11), \quad 60 \mu \mathrm{g} / \mathrm{ml}(5.31 \pm 0.12)$ and $80 \mu \mathrm{g} / \mathrm{ml}$ $(5.70 \pm 0.09)$ relative to control $(5.93 \pm 0.11)$ (Fig. 9). The treatment with CYP significantly reduced the $\mathrm{CE}$ activity at the concentrations of $10-60 \mu \mathrm{g} / \mathrm{ml}$, while CPF increased the activity at all the concentrations tested in the study, as shown in Figure 9. 


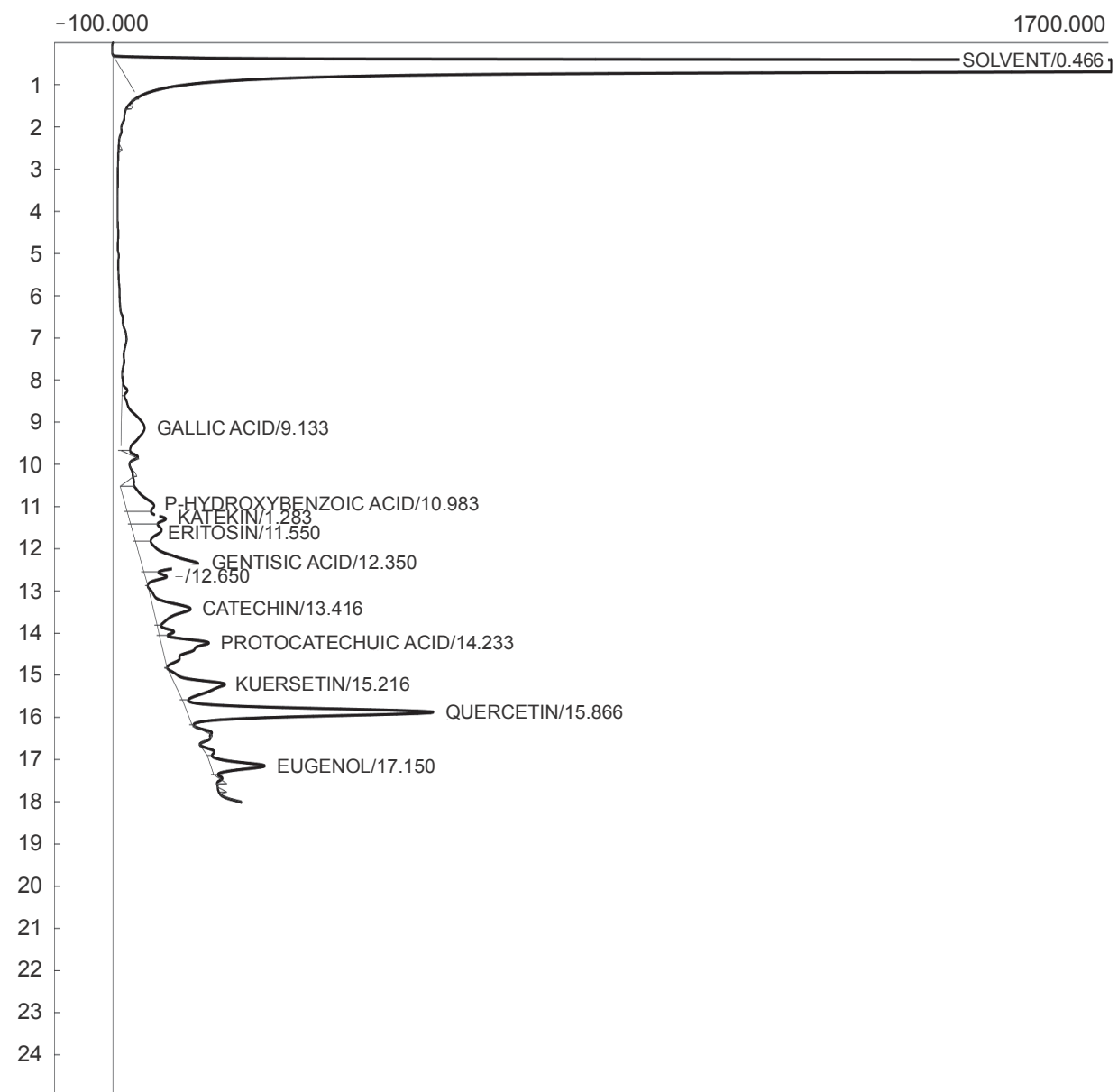

Fig. 3. Gas chromatographic chromatogram of water hyacinth methanol extract (figure shows gallic acid, p-hydroxybenzoic acid, eritosin, gentisic acid, catechin, protocatechuic acid, kuersetin, quercetin and eugenol which depicts nine prominent peaks with retention time $9.133 \mathrm{~min}, 10.986 \mathrm{~min}, 11.550 \mathrm{~min}, 12.350 \mathrm{~min}, 13.416 \mathrm{~min}, 14.233 \mathrm{~min}, 15.216 \mathrm{~min}$, $15.866 \mathrm{~min}, 17.150 \mathrm{~min}$ respectively)

\section{Discussion}

Several secondary metabolites of plant origin function as protective chemicals against insects and pathogens that prey on such plants. These compounds have structural diversity and complex biological functions (Dhivya et al., 2017). In the present study, various functional groups present in WHME were elucidated by IR and UV spectroscopy. The results of the IR of WHME show five notable peaks at $1015.7 \mathrm{~cm}^{-1}, 1457.4 \mathrm{~cm}^{-1}$, $1647.5 \mathrm{~cm}^{-1}, 2927.8 \mathrm{~cm}^{-1}$ and $3324.8 \mathrm{~cm}^{-1}$. According to the IR spectral studies by Fessenden and Fessenden (1986), Osman et al. (2010), Hossain and Ismail (2013) and Adeleke et al. (2019a), the functional groups in the extract included ether $\left(1015.7 \mathrm{~cm}^{-1}\right)$, aromatic or aryl ring $\left(1457.4 \mathrm{~cm}^{-1}\right)$, carbonyl $\left(1647.5 \mathrm{~cm}^{-1}\right)$, methyl ben- ding $\left(2927.8 \mathrm{~cm}^{-1}\right)$ and aliphatic hydroxyl or carboxylic acid $\left(3324.8 \mathrm{~cm}^{-1}\right)$ groups. Furthermore, in the present study, the UV data showed maximum absorption by the extract between 223 and $228 \mathrm{~nm}$; this indicates the presence of carbonyl group, as reported by Bulus et al. (2011). The GC-FID chromatogram of WHME showed 10 different compounds, namely gallic acid (9.73\%), parahydroxybenzoic acid (7.23\%), katekin (4.95\%), eritosin (5.32\%), gentisic acid (12.59\%), catechin (7.31\%), protocatechuic acid (9.31\%), kuersetin (8.94\%), quercetin (28.52\%) and eugenol (6.10\%). In GC-MS studies by Lenora et al. (2016) and Lenora and Senthikumar (2017), water hyacinth was reported to contain certain chemical agents such as docosane, nonacosane, camarolide and erucyclamide, which have been found to possess insecti- 
Table 1. Effects of water hyacinth (Eichornnia crassipes) methanol extract, cypermethrin, and chlorpyrifos on catalase enzyme activities in nymph and adult Periplaneta americana

\begin{tabular}{|c|c|c|c|c|c|c|}
\hline \multirow{3}{*}{$\begin{array}{l}\text { Concentration } \\
{[\mu \mathrm{g} / \mathrm{ml}]}\end{array}$} & \multicolumn{6}{|c|}{ Catalase activity $\times 10^{-3}[\mathrm{U} / \mathrm{mg}$ protein $]$} \\
\hline & \multicolumn{3}{|c|}{ nymph Periplaneta americana } & \multicolumn{3}{|c|}{ adult Periplaneta americana } \\
\hline & WHME & CYP & $\mathrm{CPF}$ & WHME & CYP & $\mathrm{CPF}$ \\
\hline 10 & $1.01 \pm 0.01$ * & $1.25 \pm 0.07$ * & $4.55 \pm 0.07$ * & $1.11 \pm 0.13^{\#}$ & $0.61 \pm 0.07^{\#}$ & $1.30 \pm 0.01$ \\
\hline 20 & $1.25 \pm 0.07^{*}$ & $0.34 \pm 0.01^{\#}$ & $9.55 \pm 0.07 *$ & $1.55 \pm 0.07$ & $0.34 \pm 0.01^{\#}$ & $2.65 \pm 0.07$ * \\
\hline 30 & $3.55 \pm 0.07 *$ & $2.33 \pm 0.04 *$ & $10.20 \pm 0.57$ * & $1.00 \pm 0.01^{\#}$ & $1.01 \pm 0.01^{\#}$ & $1.75 \pm 0.07$ \\
\hline 40 & $0.66 \pm 0.01$ & $0.99 \pm 0.01 *$ & $7.55 \pm 0.07$ * & $2.01 \pm 0.01$ & $0.76 \pm 0.06^{\#}$ & $3.95 \pm 0.07$ * \\
\hline 50 & $3.55 \pm 0.07 *$ & $1.33 \pm 0.04 *$ & $5.65 \pm 0.07 *$ & $1.60 \pm 0.01$ & $0.71 \pm 0.07^{\#}$ & $2.38 \pm 0.11$ * \\
\hline 60 & $0.69 \pm 0.04$ & $0.95 \pm 0.08 *$ & $4.99 \pm 0.01 *$ & $3.25 \pm 0.07 *$ & $0.63 \pm 0.05^{\#}$ & $0.99 \pm 0.01^{\#}$ \\
\hline 70 & $2.95 \pm 0.07$ * & $1.29 \pm 0.01 *$ & $3.97 \pm 0.04$ * & $1.30 \pm 0.01^{\#}$ & $0.34 \pm 0.01^{\#}$ & $1.20 \pm 0.01^{\#}$ \\
\hline 80 & $2.20 \pm 0.01 *$ & $0.99 \pm 0.01 *$ & $7.23 \pm 0.11 *$ & $1.26 \pm 0.06^{\#}$ & $0.67 \pm 0.01^{\#}$ & $0.94 \pm 0.08^{\#}$ \\
\hline Control & \multicolumn{3}{|c|}{$0.56 \pm 0.01$} & \multicolumn{3}{|c|}{$1.54 \pm 0.01$} \\
\hline
\end{tabular}

Mean \pm SD: * - significantly higher compared to control $(P<0.05)$, \# - significantly lower compared to control $(P<0.05)$; values expressed as in mean \pm standard deviation; WHME - water hyacinth methanol extract; CYP - cypermethrin; CPF - chlorpyrifos

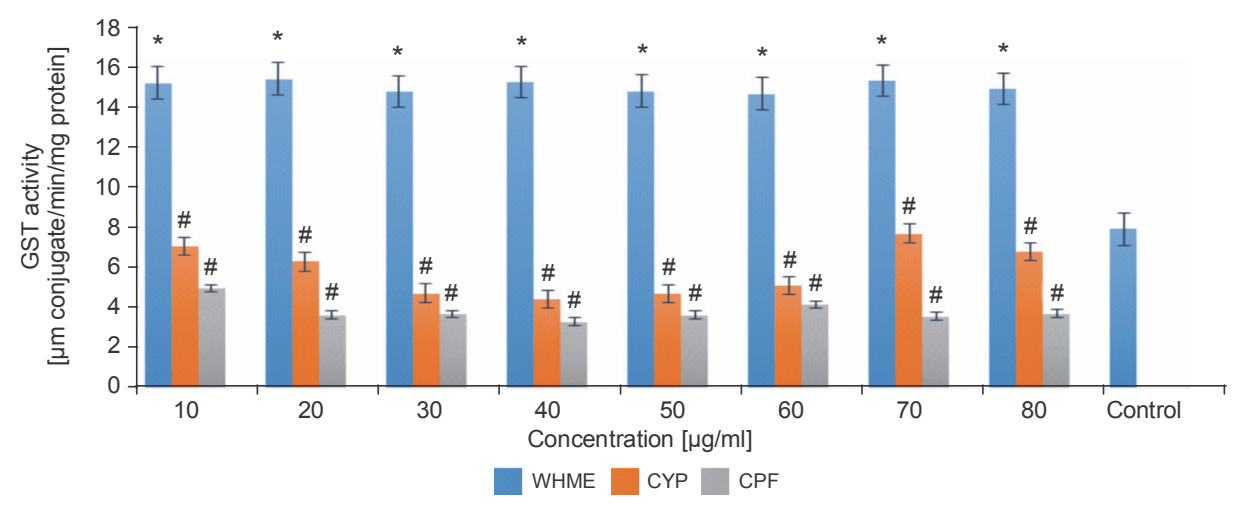

Fig. 4. Effects of WHME, CYP, CPF on Gluthatione-s-transferase activity in nymph cockroach (Periplanata americana). Mean $\pm \mathrm{SD}:{ }^{*}$ - significantly higher compared to control $(P<0.05)$, \# - significantly lower compared to control $(P<0.05)$; values expressed as in mean \pm standard deviation; WHME - water hyacinth methanol extract; CYP - cypermethrin; CPF - chlorpyrifos

cidal potential. Our findings from the present study showed that WHME is significantly rich in phenolic compounds. Some phenolics are reported to be prooxidant in insects through their oxidation to hydrogen peroxide and organic peroxides in the gut of insects (Barbehenn et al., 2005), thus showing their significant role as insect antifeedants (War et al., 2012). An earlier report by Nappi et al. (2004) indicated the presence of prophenoloxidase (PPO) enzyme in the foregut of insects, which is capable of metabolic oxidation and subsequent detoxification of phenolic compounds ingested by these insects. A further investigation by Wu et al. (2015) sug- gested that plant phenolics only become toxic in insects when there is a loss of the PPO activity due to mutation or the level of phenolics exceeds the metabolic capacity of the enzyme. Although protocatechuic acid has been reported to show an in vitro antioxidant activity ( $\mathrm{Li}$ et al., 2011), gallic acid and catechin have been shown to exert toxicity in Spodoptera frugiperda (Alves et al., 2014). Studies using quercetin have demonstrated a developmental or growth delay in Aedes aegypti (L) mosquito and mealworm beetle larvae (Gikonyo et al., 1998; Sosa et al., 2000), and an increased mortality in the wooly apple aphid Eriosoma lanigerum (Ateyyat et al., 


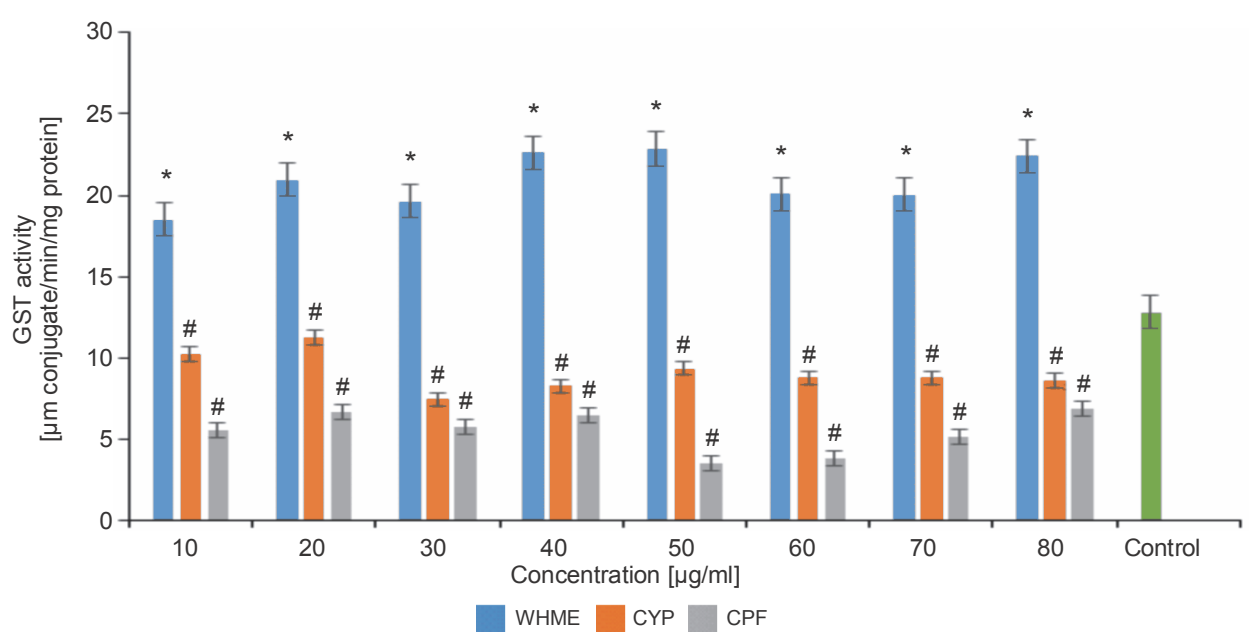

Fig. 5. Effects of water hyacinth methanol extract, cypermethrin, chloropyrifos on GlutathioneS-transferase enzyme activities in adult Periplaneta americana. Mean \pm SD: * - significantly higher compared to control $(P<0.05)$, \# - significantly lower compared to control $(P<0.05)$; values expressed as in mean \pm standard deviation; WHME - water hyacinth methanol extract; CYP - cypermethrin; CPF - chlorpyrifos

Table 2. Effects of water hyacinth (Eichornnia crassipes) methanol extract, cypermethrin, and chlorpyrifos on superoxide dismutase enzyme activities in nymph and adult Periplaneta americana

\begin{tabular}{c|c|c|c|c|c|c}
\hline \multirow{2}{*}{$\begin{array}{c}\text { Concentration } \\
{[\mu \mathrm{g} / \mathrm{ml}]}\end{array}$} & \multicolumn{6}{|c}{ Superoxide dismutase activity $\times 10^{-5}[\mathrm{U} / \mathrm{mg}$ protein] } \\
\cline { 2 - 7 } & \multicolumn{2}{|c|}{ nymph Periplaneta americana } & \multicolumn{2}{|c}{ adult Periplaneta americana } \\
\cline { 2 - 7 } & WHME & CYP & CPF & WHME & CYP & CPF \\
\hline 10 & $11.95 \pm 0.70^{*}$ & $2.95 \pm 0.07^{*}$ & $3.01 \pm 0.01^{*}$ & $6.00 \pm 0.01^{*}$ & $1.01 \pm 0.01^{\#}$ & $2.06 \pm 0.08^{\#}$ \\
\hline 20 & $3.94 \pm 0.07^{*}$ & $0.96 \pm 0.06^{\#}$ & $6.95 \pm 0.08^{*}$ & $5.95 \pm 0.08^{*}$ & $0.76 \pm 0.08^{\#}$ & $1.00 \pm 0.01^{\#}$ \\
\hline 30 & $0.99 \pm 0.01^{\#}$ & $1.85 \pm 0.21^{\#}$ & $3.70 \pm 0.42^{*}$ & $7.91 \pm 0.13^{*}$ & $2.06 \pm 0.08^{\#}$ & $0.74 \pm 0.06^{\#}$ \\
\hline 40 & $1.99 \pm 0.01^{\#}$ & $1.89 \pm 0.16^{\#}$ & $12.55 \pm 0.64^{*}$ & $1.90 \pm 0.15^{\#}$ & $0.26 \pm 0.08^{\#}$ & $0.91 \pm 0.01^{\#}$ \\
\hline 50 & $5.91 \pm 0.13^{*}$ & $0.95 \pm 0.07^{\#}$ & $4.01 \pm 0.01^{*}$ & $8.00 \pm 0.01^{*}$ & $1.00 \pm 0.01^{\#}$ & $0.98 \pm 0.04^{\#}$ \\
\hline 60 & $5.56 \pm 0.63^{*}$ & $0.93 \pm 0.11^{\#}$ & $1.96 \pm 0.06^{\#}$ & $5.03 \pm 0.04$ & $1.99 \pm 0.01^{\#}$ & $1.05 \pm 0.07^{\#}$ \\
\hline 70 & $0.99 \pm 0.01^{\#}$ & $0.88 \pm 0.18^{\#}$ & $5.95 \pm 0.07^{*}$ & $5.45 \pm 0.07$ & $5.06 \pm 0.08$ & $2.06 \pm 0.08^{\#}$ \\
\hline 80 & $0.94 \pm 0.09^{\#}$ & $2.04 \pm 0.05^{\#}$ & $0.99 \pm 0.01^{\#}$ & $3.05 \pm 0.06^{\#}$ & $2.03 \pm 0.04^{\#}$ & $4.94 \pm 0.08^{\#}$ \\
\hline Control & \multicolumn{7}{|c|}{$2.4 \pm 0.14$} & & $4.99 \pm 0.01$ & \\
\hline
\end{tabular}

Mean \pm SD: * - significantly higher compared to control $(P<0.05)$, \# - significantly lower compared to control $(P<0.05)$; values expressed as in mean \pm standard deviation; WHME - water hyacinth methanol extract; CYP - cypermethrin; CPF - chlorpyrifos

2012) and the melon fruit fly Bactrocera cucurbitae (Sharma and Sohal, 2013). Eugenol, which was identified as another constituent of WHME in the present study, has been reported to be a natural constituent of the essential oil of several plants (El-Matti et al., 2016). This compound has been shown to exert termiticidal (Xie et al., 2015), acaricidal (Ribeiro et al., 2016) and fungicidal (Koeduka et al., 2014) effects. Eugenol-rich essential oils were also reported to possess insecticidal pro- perties against Acanthoscelides obtectus, $P$. americana and Sitophilus granarius (Viteri-Jumbo et al., 2014; Polatoglu and Karatoc, 2016), meal worm beetle (Martinez et al., 2018) and cowpea weevil (Callosobruchus maculatus) (Armijos et al., 2019). In the present study, these compounds might be responsible for the insecticidal activity exhibited by WHME.

Pesticides stimulate the generation of ROS in insects, resulting in damage to biomolecules and biological acti- 


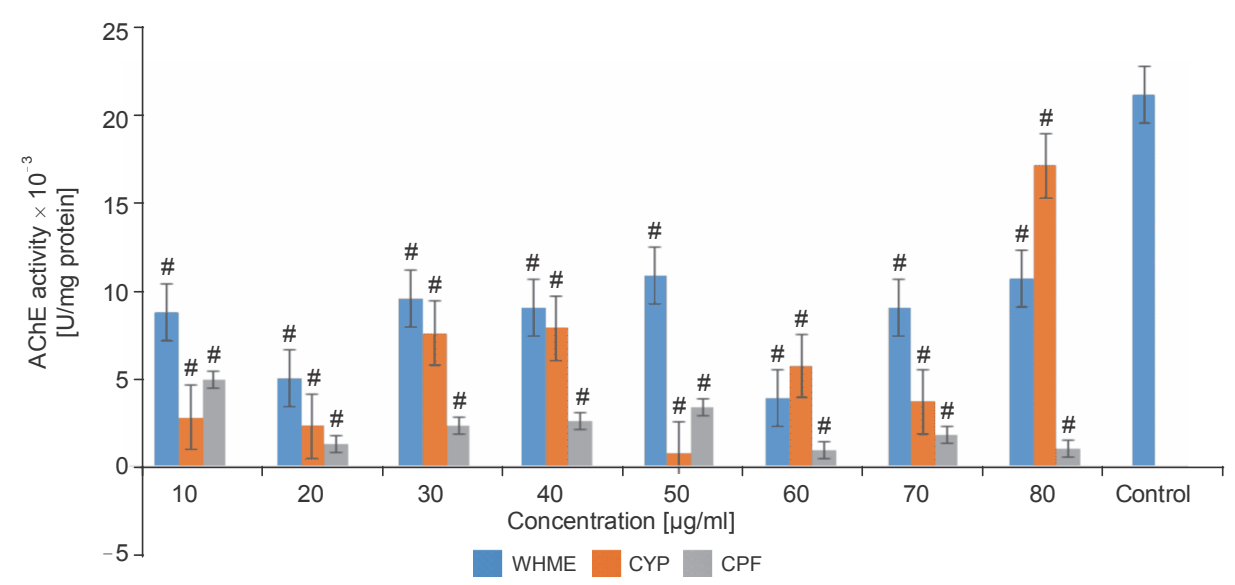

Fig. 6. Effects of WHME, CYP, CPF on acetylcholinesterase activity on Nymph cockroach (Periplaneta americana). Mean \pm SD: * - significantly higher compared to control $(P<0.05)$, \# - significantly lower compared to control $(P<0.05)$; values expressed as in mean \pm standard deviation; WHME - water hyacinth methanol extract; CYP - cypermethrin; CPF - chlorpyrifos

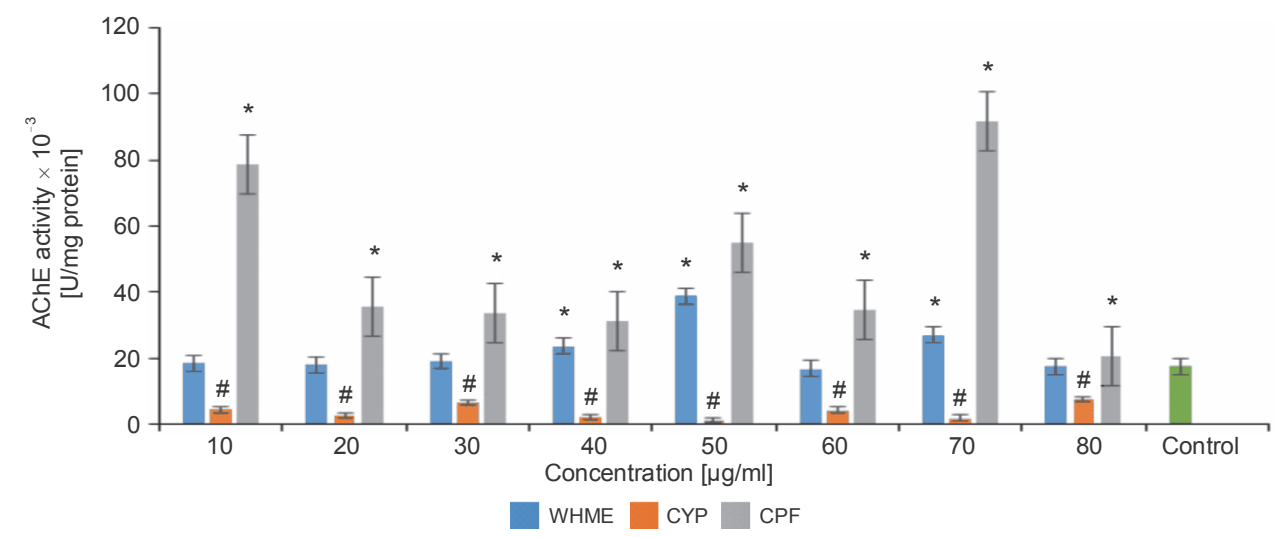

Fig. 7. Effects of water hyacinth methanol extract, cypermethrin, chlorpyrifos on acetylcholinesterase enzyme activities in adult Periplaneta americana. Values expressed as mean \pm standard deviation; * - significantly higher compared to control $(P<0.05)$; \# - significantly lower compared to control $(P<0.05)$; WHME - water hyacinth methanol extract; AChE - acetylcholinesterase

vities (Narendra et al., 2007; Zhu et al., 2016). This damage may trigger transcriptional disruption and downregulation of antioxidant enzyme-coding genes, resulting in the mortality of the insects (Abolaji et al., 2015, 2016). Our study of the catalase and SOD activities showed that WHME, CYP and CPF significantly increased the catalase activity in nymph $P$. americana, while this activity was reduced in the adult insect. The SOD activity was reduced by all the three agents in the nymph cockroach, whereas in the adult form, it was substantially increased by WHME but reduced by both CYP and CPF. In living cells, the first line of the antioxidant defence is the SOD enzyme that catalyses the dismutation of superoxide anion to hydrogen peroxide, which is finally decomposed to water and molecular oxy- gen (Mates et al., 1999; Koslov and Weidinger, 2015). Previous studies have indicated complexity in the nature of the antioxidant enzymatic system through which insects protect themselves from the toxic effects of ROS generated from plant toxins and insecticides (Felton and Summer, 1995; Rajapakse and Walter, 2007). High activities of the SOD and catalase have been implicated in the detoxification of ROS in Cimex lectularius (Mamidala et al., 2012) and Anopheles arabiensis (Nardini et al., 2013), thus enhancing the innate mechanism of resistance to ROS-generating pesticides in these insects. One of our earlier studies (Adeleke et al., 2019a) demonstrated that CYP, CPF and seed kernel extract of castor inhibit SOD and catalase in two local species of flea beetle, namely Podagrica sjosdteti and Podagrica 


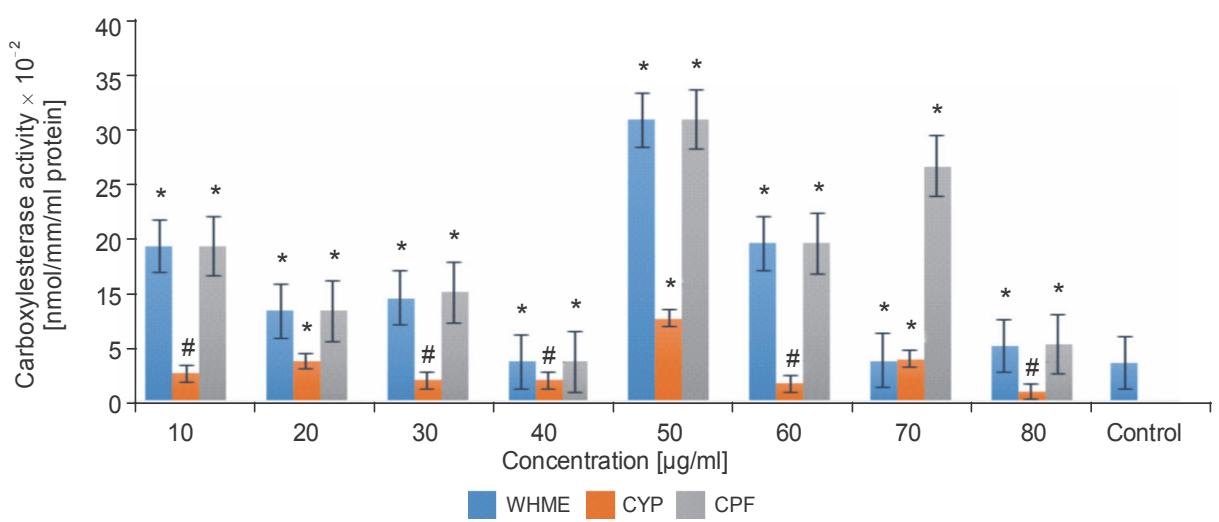

Fig. 8. Effects of WHME, CYP, CPF on carboxylesterase activity in nymph cockroach (Periplaneta americana). * - significantly higher compared to control $(P<0.05)$; \# - significantly lower compared to control $(P<0.05)$; values expressed as in mean \pm standard deviation;

WHME - water hyacinth methanol extract; CYP - cypermethrin; CPF - chlorpyrifos

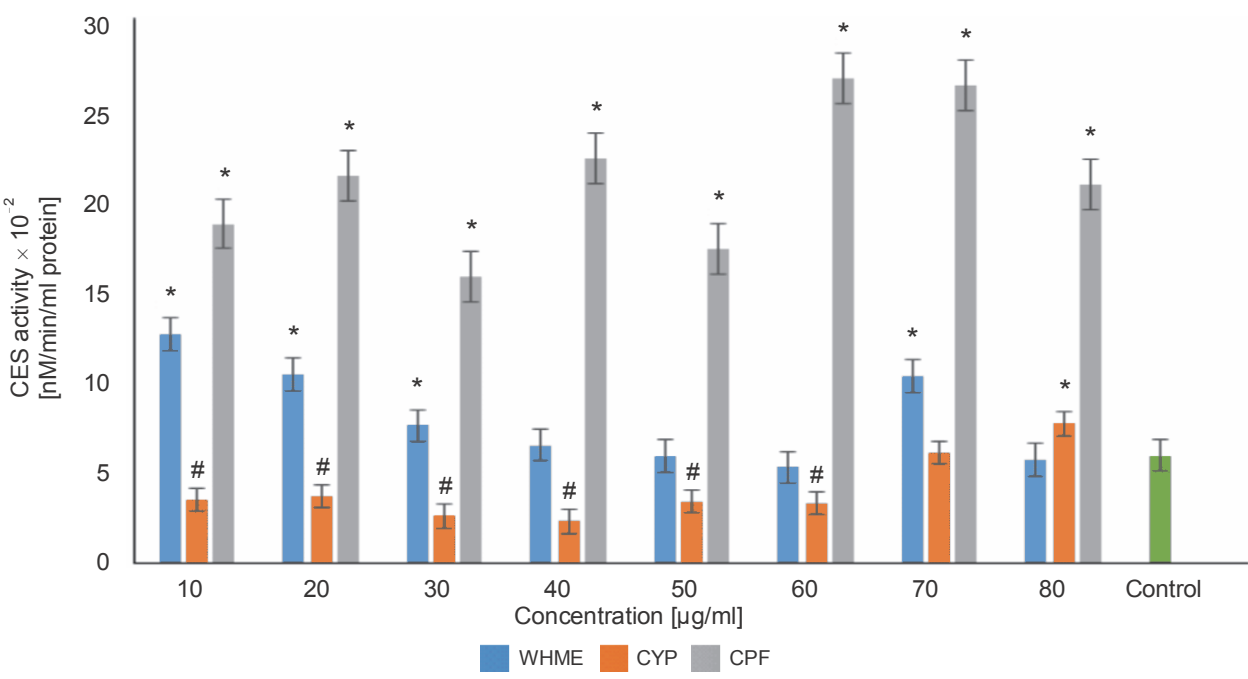

Fig. 9. Effects of water hyacinth methanol extract, cypermethrin, chlorpyrifos on carboxylesterase enzyme activities in adult Periplaneta americana. Data expressed as mean \pm standard deviation; WHME - water hyacinth methanol extract; CYP - cypermethrin; CPF - chlorpyrifos; * - significantly higher compared to control $(P<0.05)$; \# - significantly lower compared to control $(P<0.05)$

uniforma. The induction of the SOD activity coupled with the inhibition of the catalase activity by WHME in the adult $P$. americana, as observed in this investigation, may lead to the accumulation of hydrogen peroxide and the subsequent generation of oxidative stress in the insect. A study by Dhivya et al. (2017) indicated that antioxidant and detoxifying enzymes play significant roles in protecting tissues against oxidative damage. GSTs are a group of phase II detoxifying enzymes that catalyse the conjugation of several exogenous and endogenous electrophilic compounds with reduced glutathione to protect cellular macromolecules against oxidative stressinducing agents (Edwards et al., 2000; Waczuk et al., 2019). The activity of the GST enzyme was significantly increased by WHME at all the tested concentrations $(10-80 \mu \mathrm{g} / \mathrm{ml})$ in both nymphs and adults. However, both CYP and CPF were found to significantly reduce the GST activity in both nymphs and adults when compared with that in the control group. The increase observed in the GST activity indicates possible innate resistance of cockroach to the extract. Although the present study showed that GST activities were reduced by 
CYP and CPF in both nymph and adult cockroaches, a previous investigation by Sookrung et al. (2018) indicated insecticide resistance in cockroaches due to the increased detoxifying activity of GST. The opposing activities of SOD and catalase coupled with an enhanced GST activity following the treatment with WHME indicate a complexity in the antioxidant defence system of the investigated insect, as supported by the findings of Felton and Summer (1995) and Rajapakse and Walter (2007). The findings thus far suggest that the involvement of the antioxidant defence mechanism in cockroaches could protect them from oxidative stress-inducing agents, and this factor may be responsible for the wide spread of these insects in many household environments.

$\mathrm{AChE}$, a cholinergic enzyme, degrades acetylcholine to form acetate and choline after a synaptic transmission (Dvir et al., 2010). In the present study, the AChE enzyme activity in the nymph cockroach was observed to be significantly reduced by WHME, CYP and CPF. However, in the adult cockroaches, although CYP reduced the AChE activity, CPF increased it significantly, while WHME showed no significant effect. Because the nymph stage is an early stage of development, the reduction in the $\mathrm{AChE}$ activity due to the three agents indicates a low production level of the enzyme and thus a high susceptibility of the cholinergic system at the nymph stage, which may not be the case at the adult stage of the insect. When mammals are exposed to carbamates and organophosphates, the AChE enzyme undergoes irreversible inhibition, resulting in an unending excitation and contraction of the muscle (Cochran, 2011). Studies have shown the activity of AChE in many insects, including mosquitoes (Kim and Lee, 2013), flea beetles (Adeleke et al., 2019a) and grasshopper (Adeleke et al., 2019b). In insects, the acetylcholine-binding nicotinic receptor is a major target for many toxicants that affect the central nervous system (Waczuk et al., 2019). A recent study (Saad et al., 2018) using Sitophilus oryzae reported that eugenol, one of the compounds identified in the extract used for this study, could readily penetrate the cuticle of this insect to inhibit the activities of AChE and adenosine triphosphatases (ATPases). In both nymph and adult $P$. americana, WHME and CPF significantly increased the in vitro activity of the CE enzyme, whereas CYP reduced the activity of this enzyme when compared with the control. A study by Jackson et al. (2010) indicated the hydrolytic role of the $\mathrm{CE}$ enzyme in the resistance and protection of insects against organophosphate insecticides. However, the enzyme has been reported to be inactive in detoxifying deltamethrin (pyrethroid) and carbaryl insecticides applied against Locusta migratoria, the migratory locust (Zhang et al., 2013). The upregulation of the genes encoding $\mathrm{AChE}$ and $\mathrm{CE}$ enzymes has been reported to correlate positively with the resistance of ticks to pyrethroids and organophosphates (Cossio-Bayugar et al., 2009). Our earlier investigation using a local species of flea beetles, namely Podagrica sjosdteti, showed that $\mathrm{CPF}\left(\mathrm{IC}_{50}=2.65 \mu \mathrm{g} / \mathrm{ml}\right)$ and $\mathrm{CYP}\left(\mathrm{IC}_{50}=2.37 \mu \mathrm{g} / \mathrm{ml}\right)$ inhibited the in vitro activity of the $\mathrm{CE}$ enzyme (Adeleke et al., 2019a). The present study thus suggests that the elevated activities of both $\mathrm{AChE}$ and $\mathrm{CE}$ enzymes in adult cockroaches could be due to the high levels of production of these esterases. The induction of these enzymes may enhance resistance, which could be a possible mechanism underlying the wide spread of $P$. americana in homes and offices.

\section{Conclusion}

The results of the present study showed that WHME might contain some insecticidal properties, although with lower efficacy than that of the commercial insecticides CYP and CPF. Our study showed that the water hyacinth leaf methanol extract contains a high level of phenolics which may induce the activities of the antioxidant enzymes, $\mathrm{AChE}$ and $\mathrm{CE}$ in $P$. americana. The present study showed that the efficacy and the mode by which the extracts could induce toxicity depend on the growth stage of the cockroach.

\section{References}

Abolaji A.O., Adedara I.A., Abajingin A.O., Fatunmibi O.J., Ladipo E.O., Farombi E.O. (2016) Evidence of oxidative damage and reproductive dysfunctiona ccompanying 4-vinylcyclohexene diepoxide exposure in female Wistar rats. Reprod. Toxicol. 66: 10-19.

Abolaji A.O., Kamdem J.P., Lugokenski T.H., Farombi E.O., Souza D.O., da SilvaLoreto, E.L., Rocha J.B. (2015) Ovotoxicants 4-vinylcyclohexene 1,2-monoepoxideand 4-vinylcyclohexene diepoxide disrupt redox status and modify different electrophile sensitive target enzymes and genes in drosophila melanogaster. Redox. Biol. 5: 328-339

Acero L.H. (2018) Cashew (Anacardium occidentale) nut shell ethanol extreact in the control of Cockroach (Periplaneta Americana). Sci. Int. (Lahore). 30(3): 427-429.

Adeleke G.E., Adedosu O.T., Adeyi O.A., Fatoki J.O. (2019b) In-vitro effects of Rcinus communis seed kernel extract on 
some antioxidant and hydrolytic enzymes in nymph and adult Zonocerus variegatus (Grasshopper). Pan Afr. J. Life Sci. 3: 129-137.

Adeleke G.E., Ehigie L.O., Olayioye A., Oyegoke O.O., Adedosu O.T., Raheem O.K., Ugbor C.M. (2019a) Chemical analysis of Ricinus communis (Euphorbaceace) seed kernel extract and its in-vitro toxicity in two Podagrica species (Coleoptera: Chrysomelidae). Adv. Life Sci. Technol. 75: 33-49.

Aebi H. (1984) Catalase in vitro. [in:] Methods in enzymology. Ed. Packer L. Orlando FL. Academic Press: 121-126.

Ali H., Lata N., Ahi J., Ganesh N. (2010) Evaluation of woundhealing activity of Eichhornia crassipes: a novel approach. Drug Inv. Today. 2: 212-214.

Ali H., Patel M., Ganesh N., Ahi J. (2009) The world's worst aquatic plant as a safe cancer medicine - antitumor activity on melanoma induced mouse by Eichhornia crassipes. in vivo studies. J. Pharm. Res. 2: 1365-1366.

Alves A.P., Correa A.D., Alves D.S., Saczk A.A., Lino J.B.R., Carvalho G.A. (2014) Toxicity of the phenolic extract from Jabuticabeira (Myrciaria cauliflora (Mart) O. Berg) fruit skins on spodoptera frugiperda. Chilean J. Agric. Res. 74(2). http://dx.doi.org/10.4067/ S0718-58392014000200011

Anchor Pest Control (2008) Professional pest prevention program. Updated in 2008.www.anchorpestcontrol.com

Annie S.W., Raveen R., Paulraj M.G., Samuel T., Arivoli S. (2015) Screening of Eichhornia crassipse (Mart) solms (Pontederiaceae) crude laef extracts for larvacidal efficacy against the filarial vector Culex quinquefasciatus Say (Diptera: Cukicidae). Int. J. Mosquito Res. 2(4): 43-48.

Anonymous (2004) Cockroach feeding habbits. www. cockroach-picture,s.com/cockroach_feeding_habits.htm

Armijos M.J.G., Jumbo L.O.V., Faroni L.R.D., Oleivera E.E., Flores A.F., Heleno F.F., Haddi K. (2019) Fumigant toxicity of eugenol and its negative effects on biological development of Callosobruchus maculatus $L$. Rev. Cien. Agricol. 36(1): 5-15.

Ateyyat M., Abu-Romman S., Abu-Darwish M., Ghabeish I. (2012) Impact of flavonoids against woolly apple aphid, Eriosoma lanigerum (Hausmann) and its sole parasitoid, Aphelinus mali (Hald). J. Agr. Sci. 4: 227-236.

Barbehenn R., Dodick T., Poopat U., Spencer B. (2005) Fenton-type reaction and iron concentrations in in the midgut fluids of free-feeding caterpillars. Arch. Insect Biochem. Physiol. 60: 32-43.

Barrett S.C.H., Forno I.W. (1982) Style morph distribution in new world populations of Eichhornia crassipes (Mart) Solms-Laubach (Water hyacinth). Aquatic Bot. 13: 299-306.

Bhat B.A., Varma A., Saxena G. (2012) Comparative study on the acute toxicity of plant based pesticide Kethrin and an organophosphate pesticide, dichlorous to Labeo rohita. India J. Life Sci. 2(1): 95-98.

Bido G., Ferrarese M.L.L, Marchiosi R., Ferrarese-Filho O. (2010) Naringenin inhibits the growth and stimulates the lignification of soybean root. Braz. Arch. Biol. Technol. 53: 533-542.
Bonnefoy X., Kampen H., Sweeney K (2008) Public health significance of Urban Pests. World Health Organization: Copenhage, Denmark.

Brenner R.J., Krame R.D. (2019) Cockroaches (Blattaria). Medical and Veterinary Entomology. Chapter 6: 61-77.

Bulus A., Abdu K.H., Mohanned I., Umar U.P., Tarfa D.F, Chido A.B., Gamaniel K.S. (2011). Structural characterization of $Z S-2 A$ : an antiplasmodial compound isolated from Zizyphus spina-christi Root Bark. J. Pharm. Nutr. Sci. 1: $48-53$

Chaudhary C., Kanwar R.K., Sehgal A., Cahill D.M., Barrow C.J., Sehgal R., Kanwar J.R. (2017) Progress on Azadirachta indicabased biopesticides in replacing synthetic toxic pesticides. Front. Plant Sci. 8: 610.

Christopher O.T. (2002) Firefly Encyclopedia of insects and spiders. ISBN 1-55297-612-2 PP 126-128

Clement J.G., Erhardt N. (1990) Serum Carboxylesterase activity in various strains of rats: sensitivity to inhibition by CBDP(2-O-cresyl4H:1::3:2-benzodioxaphosphorin-2-oxide). Arch. Toxicol. 64: 414-416.

Cochran R. (2011) Oxime-assisted acetylcholinesterase catalytic scavengers of organophosphates that resist aging. J. Biol. Chem. 286(34): 29718-29724.

Cossio-Bayugar R., Miranda-Miranda E., Portilla-Salgado D., Osorio-Miranda J. (2009) Quantitative PCR detection of cholinesterase and carboxylesterase expression levels in Acaricide resistant Rhipicephalus (Boophilus) microplus. J. Entomol. 6(2): 117-123.

Dhivya K., Vengateswari G., Arunthirumeni M., Karthi S., Senthil-Nathan S., Shivakumar M.S. (2017) Bioprospecting of Prosopis juliflora ( $S_{W}$.) DC seed pod extract effect on antioxidant and immune system of Spodoptera litura (Lepidoptera: Noctuidae). Physiol. Mol. Plant Pathol. 101: 45-53.

Dvir H., Silman I., Harel M., Rosenberry T.L., Sussman J.L. (2010) Acetylcholinesterase: from 3D structure to function. Chemicobiological interactions. 187: 10-22.

Edwards R., Dixon D.P., Walbot V. (2000) Plant glutathione S-transferases: enzymes with multiple functions in sickness and in health. Trends Plant Sci. 5(5): 193-198.

Ellman G.L., Courtney K.D., Andres V. Jr., Featherstone Y. (1961) A new and rapid colorimetric determination of acetylcholinesterase activity. Biohem. Pharmacol. 7: 88-95.

El-Matti M.F.A., Mahgoub S.A., Labib S.M., Al-Gaby A.M., Ramadan M.F. (2016) Phenolic extract of cloves (Syzgium aromaticum) with novel antioxidant and antibacterial activities. Eur. J. Integrat. Med. 8(4): 494-504.

Ennan E., Beigler M., Kende A. (1998) Insecticidal action of terpenes and phenols to cockroaches effects on octopamine receptors. [in:] Proceedings of the International Symposium on Plant Protection, Ghent, Belgium.

Felton G.W., Summers C.B. (1995) Antioxidant systems in insects. Arch. Insect. Biochem. Physiol. 29: 187-197.

Fessenden R.J., Fessenden J.S. (1986) Organic chemistry (3 ed.). Brooks/Cole Publishing Company, Monterey, California. 
Freedman B.C., Beattie G.A. (2008) An overview of plant defences against pathogens and herbivores. Plant Health Instructor. Doi: 10.1094/PHI-1-2008-0226-01

Gikonyo N.K., Nwangi R.W., Midiwo J.O. (1998) Toxicity and growth-inhibitory activity of Polygonum senegalense (Meissn) surface exudate against Aedes aegypti larvae. Int. J. Tropical Insect Sci. 18: 229-234.

Gopal B. (1987) Water hyacinth. Elsevier. Amsterdam, The Netherlands: 471.

Goswami P.C., Nag B., Sharma A.K., Archana B., Singh H.D., Baruh J.N. (1983) Water hyacinth as a prospective source of stigmasterol. Curr. Sci. 52: 806-809.

Habig W., Pabst M., Jakoby W. (1974) Glutathione S-transferases. The first enzymatic step in mercapturic acid formation. J. Biol. Chem. 249: 7130-7139.

Hassan H.A. (2013) The effect of water hyacinth, Eichhornia crassipes, and King-Bo compound on some biological and biochemical aspects of cotton leaf worm Spodoptera littoralis (Boisd). Egypt. Acad. J. Biol. Sci. 5(1): 33-45.

Hossain M.A., Ismail Z. (2013) Isolation and characterization of triterpenes from the leaves of Orthosiphon stamineus. Arab J. Chem. 6: 295-298.

Isman M.B. (2006) Botanical insecticides, deterrents, and repellents in modern agriculture and an increasingly regulated world. Ann. Rev. Entomol. 51: 45-66.

Jackson C.J., Oakeshott J.G., Sanchez-Hernandez J., Wheelock C. (2010) Carboxylesterases in the metabolism and toxicity of pesticides. [in:] Acetylcholinesterase Pesticides. Metabolism, Neurotoxicity and Epidemiology. Ed. Satoh T., Gupta R.C. New York: Wiley: 57-77.

Jayanthi P., Lalitha P. (2013) Antimicrobial activity of solvent extracts of Eichhornia crassipes (Mart.) Solms. Pharma Chem. 5(3): 135-140.

Jayanthi P., Lalitha P., Sujitha R., Thamaraiselvi A. (2013) Anti-inflammatory activity of the various solvent extracts of Eichhornia crassipes (Mart.) Solms. Int. J. Pharm.Tech. Res. 5(2): 641-645.

Kim Y.H., Lee S.H. (2013) Which acetylcholinesterase functions as the main catalytic enzyme in the Class Insecta? Insect Biochem. Mol. Biol. 43: 47-53.

Koeduka T., Sugimotto K., Watanabe B., Someya N., Kawanishi D., Gottoh T., Ozawa R., Takabayashi J., Matsui K., Hiratake J. (2014) Bioactivity of natural O-prenylated phenylpropenes from Illicium anisatum leaves and their derivatives against spider mites and fungal pathogens. Plant Biol. 16(2): 451-456.

Koslov A.V., Weidinger A. (2015) Biological activities of reactive oxygen and nitrogen species: oxidative stress versus signal transduction. Biomolecules 5: 472-484.

Lalitha P., Sripathi K.S., Jayanthi P. (2012) Secondary metabolites of Eichhornia crassipes (Water hyacinth): a review (1949 to 2011). Natural Product Commun. 7(9): 1249-1256.

Lenora L.M., Senthilkumar J., Murugesan S., Senthilkumar N. (2016) GC-MS-MS analysis of Alien invasive aquatic weed, Eichhornia crassipes (Mart) Solms. Chem. Sinica 7: $48-52$.
Lenora L.M., Senthilkumar N. (2017) Insecticidal potential of aquatic alien weed, Eichhornia crassipes (Mart) Solms on Tobacco caterpillar, Spodoptera litura $(F)$. Asian J. Plant Sci. Res. 7(1): 1-6.

Li X., Wang X., Chen D., Chen S. (2011) Antioxidant activity and mechanism of protocatehuic acid in-vitro. Func. Foods Health Disease 7: 232-244.

Lima R.K. (2006) Caracterizacao bioquimica e bioatividades do oleo essencial de folhas de goiabeira sobre a Lagarta-doCartucho do Milho. Universidade Federal de Lavras, Lavras, Brazil, 2006

Lionetto M.G., Caricato R., Calisi A., Schettino T. (2011) Acetylcholinesterase inhibition as a relevant biomarker in environmental monitoring: new insights and perspectives. Ecotoxicology Around the Globe, Nova Science Publishers: 87-116 (Chapter 3).

Liu C.C., Zhao G.L., Li Y.N., Ding Z.P., Liu Q.G., Li J.L. (2010) Contribution of phenolics and flavonoids to antioxidant activity of ethanol extract from Eichhornia crassipes. Adv. Mater. Res. 156-157: 1372-1377.

Lowry O.H., Rosbrough N.J., Farr A.L., Randall R.J. (1951) Protein measurement with the Folin-phenol reagent. J. Biol. Chem. 193: 265-275.

Mamidala P., Wijeratne A.J., Wijeratne S. et al. (2012) RNASeq and molecular docking reveal multi-level pesticide resistance in the bed bug. BMC Genomics. 13: 6 .

Martinez L.C., Plata-Rueda A., Colares H.E., Campos J.M., Dos Santos M.H., Fernades F.L., Serrao J.E., Zanuncio J.C. (2018) Toxic effects of two essential oils and their constituents on the mealworm bettle, Tenebrio molitor. Bull. Entomol. Res. 108: 716-725.

Mates J., Perez-Gomez C., Nunez de Castro I. (1999) Antioxidant enzymes and human diseases. Clin. Biochem. 32: 595-693.

Milatovic D., Gupta R.C., Aschner M. (2006) Anticholinesterase toxicity and oxidative stress. Sci. World J. 6: 295-310.

Misra H.P., Fridovch J. (1975) The role of superoxide anion in the autoxidation of epinephrine and a simple assay for superoxide dismutase. J. Biol. Chem. 247: 3170-3175.

Mullen C., Durden, L. (2002) Medical and veterinary entomology. ISBN 0-12510-451-0P.32

Nachmanshon D., Neumann E. (1975) Chemical and molecular basis of nerve activity. Academic Press, New York.

Nappi A., Kohler L., Mastore M. (2004) Signaling pathways implicated in the cellular innate immune system responses of Drosophila. Invertebr. Survival J. 1: 5-33.

Nardini L., Christian R.N., Coetzer N., Koekemoer L.L. (2013) DDT and pyrethroid resistance in Anopheles arabiensis from South Africa. Parasit Vectors. 6: 229.

Narendra M., Bhatracharyulu N., Padmavathi P., Varadacharyulu N. (2007) Prallethrin induced biochemical changes in erythrocyte membrane and red cell osmotic haemolysis in human volunteers. Chemosphere 67(6): 1065-1071.

Ogunleye R.F. (2010) Toxicity bioassays of four different botanicals against the house hold pest: Periplaneta americana (Linnaeus). J. Sci. Technol. 30(2): 29-34. 
Osman O., Atia F., Hakeem N.A., Al Neklawy M.M., Fahem A. (2010) Molecular spectroscopic study of water hyacinth collected from different media. Austral. J. Basic Appl. Sci. 4(12): 6134-6139.

Ozdemir O. (2014) Cockroach allergey, respiratory allergic disease and its immunotherapy. Int. J. Immunol. Immunother. 1: $1-5$.

Pavela R., Benell G. (2016) Essential oils as eco-friendly biopesticides? Challenges and constraints. Trend Plant Sci. 219(12): 1000-1007.

Piper G.L., Antoneli A.L. (2007) Cockroaches: identification, biology and control. Second Edition Green publishers Inc. Bourdex: 70.

Polatoglu K ., Krakoc O.C. (2016) Chapter 5 - Biologically active essential oils against stored product pests A2. [in:] Essential oils in food preservation, flavour and safety. Ed. Preedy V.R. San Diego. Academic press: 39-59.

Pomes A., Wunschmann S., Hindley J., Vailes L.D., Chapman M.D. (2007) Cockroach allergens: Function, structure and allergenicity. Protein Peptide Lett. 14: 960-969.

Rajapakse C.N.K., Walter G.H. (2007) Polyphagy and primary host plants: oviposition preference versus larval performance in the lepidopteran pest Helicoverpa armigera. Arthropod Plant Interact. 1: 17-26.

Ribeiro N., Camara C., Rasmos C. (2016) Toxicity of essential oils of Piper marginatum Jacq. Against Tetranychus urticase Koch and Neoseiulus californicus (McGregor). Chilean J. Agric. Res. 76(1): 71-76.

Saad M.M., Abou-Taled H.K., Abdelgaleil S.A. (2018) Insecticidal activities of monoterpenes against Sitophilus oryzae and their inhibitory effects on acetylcholinesterase and adenosine triphosphatases. Appl. Entomol. Zool. 53(2): 173-181.

Sharma R., Sohal S.K. (2013) Bioefficiency of quercetin against melon fruit fly. Bull. Insectol. 66(1): 79-83.

Sookrung N., Reamtong O., Poolphol R., Indrawattana N., Seesuay W., Saelim N.,Tantilipikorn P., Bunnag C., Chaicumpa W., Tungtrongchitr A. (2018) GlutathioneS-transferase (GST) of American cockroach, Periplaneta americana: classes, isoforms, and allergenicity. Sci. Rep. 8: 484.

Sosa M.E., Tonn C.E., Guerreiro E., Giordano O.S. (2000) Bioactividad de flavonoides sobre larvas de Tenebrio molitor. Rev. Soc. Entomol. Argentina. 59: 179-184.

Stevenson P.C., Isman M.B., Belmain S.R. (2017) Pesticidal plants in Africa: a global vision of new biological control products from local uses. Ind. Crops Prod. 110: 2-9.

Tholl D. (2006) Terpene synthases and the regulation, diversity, and biological roles of terpne metabolism. Curr. Opin. Plant Biol. 9: 29-35.
Valicentre F.H, Picoli E.A.T, Vasconcelos M.J.V, Carneiro N.P, Carneiro A.A, Guimarães C.T, Lana U.G. (2010) Molecular characterization and distribution of Bacillus thuringiensis cry1 genes from Brazilian strains effective against the fall armyworm, Spodoptera frugiperda. Biol. Control 53: 360-366.

Villamagna A.M., Murphy B.R. (2010) Ecological and socioeconomic impacts of invasive water hyacinth (Eichhornia crassipes): a review. Freshw. Biol. 55: 282-298.

Viteri-Jumbo L.O., Faroni L.R., Olivera E.E., Pimentel M.A., Silva G.N. (2014) Potential use of clove and cinnamon essential oils to control the bean weevil, Acanthoscelides obstectus Say, in small storage units. Ind. Crops Prod. 56: 27-34.

Waczuk E.P., Wagner R., Bruna K., da Rocha J.T., ArdissonAraújo D.M.P., Barbos N.V. (2019) Assessing the toxicant effect of spontaneously volatilized 4-vinylcyclohexane exposure in nymphs of the lobster cockroachnauphoeta Cinerea. Environ. Toxicol. Pharmacol. 72: 1-7.

War A.R., Paulraj M.G., Ahmad T., Buhroo A.A., Hussain B., Ignacimuthu S., Sharma HC. (2012) Mechanisms of plant defense against insect herbivores. Plant Signal Behav. 7: 1306-1320.

Wu K., Zhang J., Zhang Q., Zhu S., Shao Q., Clark K.D., Liu Y. (2015) Plant phenolics are detoxified by prophenoloxidase in the insect gut. Sci. Rep. 5(1): 16823.

Xie L.J., Zeng R.S., Bi H.H., Song Y.Y., Wang R.L., Su Y.J., Chen M., Chen S., Liu Y.H. (2010) Allelochemical mediated invasion of exotic plants in China. Allelopathy J. 25: 31-50.

Xie Y., Yang Z., Cao D., Rong F., Ding H., Zhang D. (2015) Antithermitic and antifungal activities of eugenol and its congeners from the flower buds of Syzgiun aromaticum (cloves). Ind. Crops Prod. 77: 780-786.

Yu M., Tsunoda H., Tsunoda M. (2012) Environmental toxicology: biological and health effects of pollutants. (Ed. 3) CRC press. N.Y, United States of America: 148-150.

Zhang J., Li D., Zhang J. (2013) RNA interference revealed the roles of two carboxylesterase genes in insecticide detoxification in Locusta. Migratoria. Chemosphere 4: 43.

Zhu E.H., Chen N., Liu M.Y., Li J., Li D., Yang Y.S., Zhang Y., He D.F. (2016) Isomers and their metabolites of endosulfan induced cytotoxicity and oxidative damage in $\mathrm{SH}$ SY5Y cells. Environ. Toxicol. 31(4): 496-504.

Zhu K.Y., Clark J.M. (1997) Validation of a point mutation of acetylcholinesterase in Colorado potato beetle by polymerase chain reaction coupled to enzyme inhibition assay. Pestic. Biochem. Physiol. 57(1): 28-35. 